\title{
The Sorbonne and Bologna Declarations on European Higher Education
}

\section{Hans de Wit}

Hans de Wit is vice president for international affairs at the University of Amsterdam, the Netherlands. Address: PO Box 19628, Amsterdam, the Netherlands 1000GG. E-mail: <hansdw@bdu.uva.nl>.

$\mathrm{O}$ n June 19, 1999, in Bologna, Italy, ministers of education of 29 European countries signed the Declaration on the European Higher Education Area. The joint declaration was based on the understanding that:

a Europe of Knowledge is now widely recognised as an irreplaceable factor for social and human growth and as an indispensable component to consolidate and enrich the European citizenship, capable of giving its citizens the necessary competences to face the challenges of the new millenium, together with an awareness of shared values and belonging to a common social and cultural space. The importance of education and educational co-operation in the development and strengthening of stable, peaceful and democratic societies is universally acknowledged as paramount, the more so in view of the situation in South East Europe.

The broad support for this declaration beyond the member states of the European Union is unique and has attracted broad international attention. This article looks at the impetus for this declaration, its goals, and the changes envisioned.

In the declaration, the ministers outline the following objectives:

- adoption of a system of clear and comparable degrees, including the adoption of a "Diploma Supplement";

- adoption of a system based on two main cycles-undergraduate and graduate;

- establishment of a system of credits—such as the European Credit Transfer System-as a means of promoting student mobility;

- promotion of mobility by overcoming obstacles to the effective exercise of free movement;

- promotion of European cooperation in quality assurance; and

- promotion of common European patterns in higher education.

The groundwork for what is already widely known in higher education as the Bologna Declaration was laid by the Sorbonne Declaration, signed on May 25, 1998 in Paris by the ministers of education of France, Germany, Italy, and the United Kingdom on the occasion of the anniver- sary of the university of Paris. In this "Joint declaration on harmonization of the architecture of the European higher education system," the ministers of four dominant countries of the European Union, stated that

[Europe is] heading for a period of major change in education and working conditions, to a diversification of courses of professional careers, with education and training throughout life becoming a clear obligation. We owe our students, and our society at large, a higher education system in which they are given the best opportunities to seek and find their own area of excellence. An open European area for higher learning carries a wealth of positive perspectives, of course respecting our diversities, but requires on the other hand continuous efforts to remove barriers and to develop a framework for teaching and learning, which would enhance mobility and an ever closer cooperation.

The Sorbonne Declaration was a French initiative based on the Attali Report, "Pour un modèle européen d'enseignement supérieur," which compares the French system with other European systems of higher education as the basis for a reform of the French system. The declaration came as a surprise-not only to the higher education community but also to the European Commission and the ministers of education of the other member states. It seemed rather unlikely that four countries with fundamentally different higher education traditions would be willing to lead the way toward harmonization. Only in 1993, with the Maastricht Treaty, did education become an area in which the European Commission could take action, but only as a subsidiary focus. Thus, joint European action on higher education was not high on the agenda of the European Council of Ministers.

It appears that ministers of education of the four countries acted deliberately as representatives of their national governments, outside the context of the European Commission. Perhaps they saw this as a way to maintain control over the necessary process of harmonization. Such a proposal would have been far more difficult to sell if presented by the Commission, by one of the four larger countries, or by the smaller countries. (In reality, the smaller countries were already further on their way to accomplishing what the Sorbonne Declaration intended.) Thus, the United Kingdom needed France, Italy, and Germany to convince the British public of the advantages of a joint initiative to harmonize European higher education with the British system. The Germans, for their part, needed the support of the other countries to sell a plan at home to introduce the 
bachelor's and master's degree structure. And the French and Italians needed the others to convince their publics of the need for reform of their higher education systems, something that had previously always been blocked by massive protests.

\section{Europe is heading for a period of major change in education and working con- ditions, to a diversification of courses of professional careers, with education and training throughout life becoming a clear obligation.}

Of course, intensive debates followed, complicated by discrepancies between the French and British versions of the declaration. However, the Sorbonne Declaration was surprisingly well received, both in the political arena and in the higher education community of the four countries and in the rest of Europe. Andris Barblan of the Confederation of European Union Rectors' Conferences (CRE) gave the following explanations for this positive response during a meeting of the Santander Group:

- The process was initiated from unexpected quarters, the European role of the Commission being taken over at the national level by the education ministers.

- Politicians were calling for the fulfillment of a process they had entrusted earlier to the people primarily responsible for higher education-namely, academics.
- The discussion at the Sorbonne was an extremely rare constellation of users, providers, and political leaders.

The positive response to the Sorbonne Declaration set the stage for a broader initiative. On the invitation of the Italian minister of education, a meeting was convened in Bologna. The debate was based on the Sorbonne Declaration and on a study prepared by the Association of European Universities and the CRE on "Trends in European Learning Structures." The study showed the extreme complexity and diversity of European curricular and degree structures. Whereas the Sorbonne Declaration spoke of harmonization, both the prepared study and the resulting Bologna Declaration avoided this word-due largely to the potential negative interpretations. Instead, the study speaks of "actions which may foster the desired convergence and transparency in qualification structures in $\mathrm{Eu}-$ rope."

What effect will the two declarations have on higher education in Europe? First of all, they reconfirm trends under way in Germany, Austria, and Denmark to introduce a bachelor's and master's degree structure. Second, they have stimulated similar movements in countries such as the Netherlands, where several universities have started to develop bachelor's and master's degrees, with the support of the minister of education. But most of all, a strong incentive has been given to the realization of an open $\mathrm{Eu}-$ ropean higher education environment. The declarations, in themselves an attempt to keep a political grip on developments in the higher education sector, will work as a catalyst for reform of higher education throughout Europe. There is still a long way to go, particularly in Germany, France, Italy, and the United Kingdom, the four countries that initiated the Sorbonne Declaration.

\section{Australia and Foreign Student Recruitment}

\section{Barbara B. Burn}

Barbara B. Burn is associate provost for international programs at the University of Massachusetts, Amherst. Address: Clark International Center, Box 33280, University of Massachusetts, Amherst, MA 01003, USA. Email: <bbburn@ipo.umass.edu>.

A ustralia's universities have unquestionably gained a reputation for aggressively recruiting foreign students. Using vocabulary from the world of business (e.g., "marketing" higher education or "diversifying international student recruitment into new markets") reinforces their perceived commercial orientation. So, also, have the universities' "hard-sell" efforts, as at the annual conferences of NAFSA: Association of International Educators, where Australian university contingents appear among the most active in foreign student recruitment efforts.

On a recent two-week visit in Australia, a country on whose higher education system I earlier published two studies, one of my interests was to explore the universities' motivation and strategies for attracting more foreign students to their institutions. With Chancellor David Scott of the University of Massachusetts, Amherst, I arranged visits to six universities, met with administrators and faculty, collected information, and discussed the foreign student situation.

The active, even aggressive, foreign student recruiting started after the Commonwealth government announced a policy of full-cost fees in 1985, following the 1984 Jackson Committee review of overseas aid programs. The number of foreign students increased from 15,000 in 1984 to 75,000 in 1998 , and is projected to reach 89,000 by the 